\title{
SIGRID UNDSET'S LETTERS TO HOPE EMILY ALLEN
}

\author{
BY MARLENE CIKLAMINI \\ Dr. Ciklamini is a member of the German Department \\ of Douglass College
}

$\mathrm{I}^{\mathrm{N}}$ $\mathrm{N}$ her autobiographical sketch prepared for the awarding of the I 928 Nobel Prize for Literature, Sigrid Undset noted that as a child she had nurtured a deep distrust toward the concept of human progress. ${ }^{1}$ This pessimistic conviction deepened in the last years of her life, the period of World War II and the post-war years. During her years of refuge in the U. S. she witnessed with horror and shock the inhumanity and destruction of the Second World War. In the few years after her return to Norway she feared the fragility of peace and the possibility of a nuclear war.

The letters in the University Library's Special Collections date from those years, from February 194I until December 1948. Most are addressed to Hope Emily Allen, ${ }^{2}$ a medievalist, who became a trusted friend. Their fondness for Margery Kempe, an English mystic of the fifteenth century, led to their friendship (February 6, I94I). Sigrid Undset had written a popular essay on the mystic, housewife, and traveller, for she wanted to introduce the translation of the Butler-Bowden manuscript of Margery Kempe's Life to a wide audience; Miss Allen had written a preface for the edition of this manuscript and had collaborated on the notes and appendixes. ${ }^{3}$

Sigrid Undset's letters to Hope Allen are expansive and imaginative. They are full of descriptions enlivened by her fondness for striking detail. Much that she relates is structured in scenes recreated with an emotional and sensual ambiance like a trolley-ride through

${ }^{1}$ Les Prix Nobel en 1928 (Stockholm, 1929), p. 69.

${ }^{2} \mathrm{~A}$ few letters are also addressed to Carlotte C. Kinsley. They lack the cordiality of Sigrid Undset's letters to Hope Allen.

${ }^{3}$ Sigrid Undset, "Margery Kempe of Lynn," Men, Women and Places, trans. Arthur G. Chater (New York, I939), pp. 81-104. The Book of Margery Kempe; the Text from the Unique Ms. Owned by Colonel W. Butler-Bowden, Early English Text Society (London, 1940). 
polyglot Brooklyn. The letters all bear the stamp of her personality. She was a passionate, outspoken, and intensely committed woman who tended to be reticent about her past to the point of withdrawment. As fond as she was of Hope Allen she confided to her only little about her marriage to and her divorce from the painter Svarstad and her conversion to Catholicism. These matters were private, to be spoken of only when her heart was full and when strong memories obtruded upon her busy life.

The letters show her hectic life as a fervent patriot in exile and an outspoken critic of the Nazi regime. They reveal her anguish at the fate of relatives and friends in Norway and her hatred of all things German. As the war drew to an end she became more and more anxious to be one of the first to return home and to share the deprivations and the painful efforts to rebuild and organize the country. Surprising is the dearth of literary discussions or of references to modern works and authors. Although as a novelist she wrote both about modern and medieval times, in her letters to Hope Allen she speaks mostly of her love for medieval Scandinavian literature. The letters then, despite their intrinsic interest, cover only a narrow range of subjects, her life as a spokesman for Norway during the war, her worries about her friends and relatives in Norway, her intense hatred of Germany, her homecoming with all its joys, anxieties, and frustrations, her delight in flowers and the sagas, and an occasional glimpse of the past.

During her refuge in the United States, Sigrid Undset lived in an apartment in Brooklyn. The central location of her home accounts in part for her activity as a writer and lecturer. In part her endless occupations were due to her passionate commitment to the war cause. She would accept all engagements to speak, write, and attend luncheons, commitments her government urged her to make. She felt that this was the least she could do for her country suffering under German domination. She did at times complain of the strain and loneliness of what she called her "war work." "The people in the Norwegian embassy and Information Service and Norwegian Newspapers," she wrote plaintively, "have come to regard me as a kind of encyclopedia" (July 20, I943).

Yet she was always happy to speak about Norway: "I still get an 
opportunity to give at least some people some idea of what we really are like-not at all the simple and honest teddybears and nationalcostume maidens of Mr. Steinbecks (sic) - and some dreadful moviemakers concept" (March I8, 1943). And she would always take time to answer questions American servicemen would pose on European affairs and the post-war. "I have made it a principle always to answer these soldiers' letters as comprehensivele (sic) and well as I can" (March 18, I943).

Her intense hatred toward Germany seemed to be rooted not so much in her war work as in her anxiety for her family and friends. They were all libertarians and patriots and she justifiably feared for their safety. Her antipathy, however, knew no measure. Though she despised and shunned pretense and prejudice she would in those years condemn everything German or associated with Germany as contemptible or immoral. The quote below shows that her emotions would even distort her literary views. The passage refers to a translation of Olrik's famous collection of medieval Danish ballads which Sigrid Undset had commended to Hope Allen. ${ }^{4}$ Sigrid Undset regretted that "the Olrik collections have left out some of the ballads that most scathingly express the danish opinion of their southern neighbors-the braggart men, the bragging and whorish women, the cowardly cringing of Germans when they are down in luck" (September 3, I 943 ).

Sigrid Undset's agony at hearing of the imprisonment or torture of her relatives and friends explains her unmitigated hatred. Her

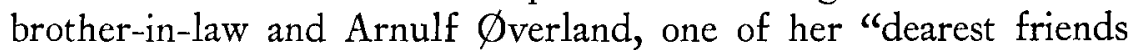
among the Norwegian authors" were arrested as early as June I 94 I (July 7, I 94I). Her godson was killed in June 1945, a few days before the liberation. Even after her return to Norway, she was constantly reminded of the torture her relatives and friends suffered during the occupation. She is proud of her friend Arnulf $\emptyset_{\text {verland }}$ who immediately after his release from the concentration camp in Sachsenhausen, wrote an article about his experiences while he was still recuperating in a Swedish hospital (May 9, I945). The husband of her niece was permanently crippled by torture. Her best

\footnotetext{
${ }^{4}$ Axel Olrik, A Book of Danish Ballads, trans. E. M. Smith-Dampier (Princeton, I939).
} 
girlhood friend died after hearing of her son's death at the hands of the Gestapo (December 6, 1945). Her dentist was maimed in Sachsenhausen (March I 8, I 946). Her sister's husband died after his release from a concentration camp (May 19, I945).

Her passionate commitment to life is felt in all her letters. Yet despite her friendship to Hope Allen she rarely spoke about the difficult periods in her own life and those of her children. A note to Hope Allen about one of her stepdaughters is typical of the privacy she owed to herself and those she loved. Sigrid Undset confided that she worried greatly about her stepdaughter, but she never divulged the cause of her anxiety. She restricted herself to an impatient comment on the character of her stepdaughter: " 44 years old by now and never a bit more sensible than she was when she was a troublesome child" (October I2, I947).

Sigrid Undset mentioned her marriage to the painter Svarstad only twice. One of the letters written two years before her death suggests how difficult their married life must have been:

Well, our marriage did not turn out a success, - he had a gift for making other people, and himself, unhappy, and to turn friends and admirers into enemies, which did much to prevent him from being recognized as the great artist he really was, as long as he was living. ... When he arranged his own exhibitions he always dragged in a lot of his worst things to give it the most prominent places and swear they were his very best. ... I am really proud of Hans ... and I like his loyalty to his father, whom he admired always without having any illusions about what life with him would have been like. To my stepdaughters it was sometimes rather like hell (February I6, 1947).

Four years earlier, when mentioning Svarstad's death, only her love for Hans, her surviving son, and her stepchildren (including her hopelessly insane stepson) is palpable: "It made a strange impression on me too of course to learn of the death of the man I have been married to, even if we did not see much of each other for years, - of course, we met whenever anything had to be decided about the children, our own as well as his three children by his first wife. I am glad to know, his daughters, my stepdaughters, were with him when he died. They are good girls, and I long very much to see them again" (October 23, I943). 
For literary critics, the letters contain disappointingly few remarks on the works of her contemporaries or on classical authors. Hope Allen was not a reader of novels. Perhaps this is the reason we hear so little about modern authors Sigrid Undset may have known or read. She cared little for T. S. Eliot, but was thrilled that in 1948 Moby Dick had finally been translated into Norwegian, and that R. P. Warren's All the King's Men and Dana's Two Years before the Mast had received enthusiastic receptions in Norway (June 29, 1943, November 14, I948). Some of her judgments, those on German authors and the portrayal of Germans in literature, are prejudiced. She detested writing a two-page contribution honoring Thomas Mann on his seventieth birthday: "As I never cared much for Thomas Mann I felt a violent disinclination to start. . . . At last I succeeded in writing two pages which sound very profound (not my line, you know), but you have to when you are going to write for Germans about things you don't want to express your real opinion on" (January I2, I945).

But talking about Old Norse literature was to chat about an old and enduring love. Her ties to the Scandinavian past were strong. Her father, a noted archeologist, had been fascinated by the early Middle Ages in Scandinavia, a period of transition half-shrouded by legend and half-illuminated by history. By examining archeological remains and written sources, he felt, one could arrive at a realistic view of medieval Scandinavian life at this era. ${ }^{5}$

Sigrid Undset's greatest literary success, Kristin Lavransdatter, a three-volume novel set in medieval Norway, redounds in part on her early training. This work won her the Nobel Prize in 1928 as well as the respect of medievalists. Sigrid Undset's medieval Norway was a fictionalized reality which to medievalists was authentic and unglamorized. As a child she had been taught to look at medieval objects from all sides, feel their weight, and trace their outlines with her hands. ${ }^{6}$ As a novelist she brooked no compromise in her

\footnotetext{
${ }^{5}$ In an autobiographical novel on her childhood, The Longest Years, trans. Arthur G. Chater (London, 1940), Sigrid Undset expressed her indebtedness to her father in a telling detail. She calls herself not Sigrid, but Ingvild in tribute to her father Ingvald. Both names, incidentally, are rooted in medieval times. In the sagas which both father and daughter enjoyed reading to each other, the names appear as Yngvild and Yngvaldr.

"Francis Bull, "Sigrid Undset," Samtiden, tidskrift for politik, litteratur og samfundssporgsmaal (1957), 269-270.
} 
conviction that the setting of her medieval works had to be real.

Several letters to Hope Allen show that she was a friend of some of the greatest Scandinavian medievalists. She worried about the imprisonment of Eiliv Skard; she sent Hope a book by an old friend, Knut Liest $\varnothing \mathrm{l}$; and she told Hope of her happiness to receive a booklet from Sigurðr Nordal in which he demonstrated, to her mind successfully, that the sagas are novels rather than historical works. In a letter dated September 19, 1943, she paid a moving tribute to the recently deceased Fredrik Paasche, one of the most prominent medievalists of that time: "He was one of the noblest and best men I ever knew. His specialty was Icelandic literature of the Middle Ages, though he was professor in Middle Hoch-Deutsch really. He was profoundly learned ... and did a splendid job emphasizing the fact that the literature of the Icelandic middle ages was a feature of the Christian culture-the Viking ages being entirely illiterate."

She also enjoyed introducing Hope Allen to some of her favorite works. When Hope Allen invested some royalties in a translation of Snorri Sturluson's Heimskringla (a history of early Norwegian kings) Sigrid Undset was elated. Shrewdly she described a scene of common interest to medievalists: How King Magnús selected ten warriors with the slimmest hands to tend his wounded men and how the healing skill of these men was passed on, grace to the thaumaturgic powers of the king, to their descendants. Half in jest, half seriously Sigrid Undset warned Hope Allen on her coming visit to Kenwood: "I shall talk saga until you get tired of me and my enthusiasm for the Old Icelanders" (January 28, r945).

Unfortunately, the University Library does not possess any of Hope Allen's letters to Sigrid Undset, but Miss Allen's interest is self-evident in Sigrid Undset's frequent references to Old Norse. When Sigrid Undset discovered that her rare editions of sagas and the Eddas had not vanished during the German occupation of Norway she was filled with joy. With malice and satisfaction she speculated on the reason for the survival of her Old Norse library: she had been fortunate that her house had not been occupied by educated German officers who would have recognized the value of her collection; rather her house had been used by a certain class 
of women without literary pretensions. And with a note of regret she told Hope Allen a commonplace often indulged in by saga enthusiasts: "You don't know what you have missed by not reading Old Norse" (May I, 1946).

None of the works which followed Kristin Lavransdatter (I 92022) and The Master of Hestviken (1925-27) attained the distinction of these historical novels. In 1925 she converted to the Roman Catholic Church. The influence of her conversion on her writings was profound. In an evaluation of her later works, James Walter $\mathrm{McF}$ arlane characterizes the artistic consequences of her conversion as "immoral," a critical term taken from D. H. Lawrence. "Morality in the novel is the trembling instability of the balance. When the novelist puts his thumb in the scale, to pull down the balance to his own predilection, that is immorality."

In her letters Sigrid Undset does not appear preoccupied with religion, although she does mention occasionally that she went to mass or that she once visited the shrine of Mother Cabrini in New York. Her devotion to Catholicism did not affect her judgment. She criticized the publications of the Saint Ansgar League for which she wrote a contribution. She commented that the first papers of the series "were rather bad and ignorant-just old Catholic propaganda chlicees (sic) picked up from books" (December 3, I943).

Sigrid Undset loved America, even though she longed to return to Norway and indeed managed to leave during the early post-war days, when only men were officially permitted to go back. She enjoyed New England and found New York beautiful on a sunny day in autumn or under a light covering of snow (October 30, 1942). After a trip through Brooklyn she wrote: "If I did not long so terrible ( sic) for my own people at home, I should say it is the most exiting ( $s i c$ ) place in the world to be, here in this part of America" (December I4, I942). Characteristically, she included in her last letter to Hope Allen (December 5, 1948) a copy of a protest she had sent to the editor of the Herald Tribune from her home in Norway. In this letter to the Herald Tribune she opposed with sentiment the discontinuance of the Hudson River Boat trips. The abolip. 168 .

7 "Sigrid Undset," Ibsen and the Temper of Norwegian Literature (London, I960), 
tion of this institution, she felt, was a disservice to those who enjoyed the beauty of the Hudson Valley. It was as if a quasi-patriotic duty had urged her to make a public appeal for the preservation of these boat excursions up the river. 